\title{
Modelling THM formation potential based on the character of organics - in catchments and drinking water sources
}

\author{
$\underline{\text { J. Awad }}^{\text {a }}$, J. van Leeuwen ${ }^{\text {a,d,e }}$, C. Chow ${ }^{\text {a,b,d, }}$, M. Drikas ${ }^{\text {a,b,d }}$ and R. J. Smernik ${ }^{\text {c }}$ \\ ${ }^{a}$ Centre for Water Management and Reuse, School of Natural and Built Environments, University of South \\ Australia, South Australia 5095, Australia \\ ${ }^{b}$ Australian Water Quality Centre, SA Water Corporation, 250 Victoria Square, Adelaide, South Australia \\ 5000, Australia \\ ${ }^{c}$ School of Agriculture, Food \& Wine and Waite Research Institute, The University of Adelaide, Waite \\ Campus, Urrbrae, South Australia 5064, Australia \\ ${ }^{d}$ SKLEAC, Research Centre for Eco-environmental Sciences, Chinese Academy of Sciences, P.O. Box 2871, \\ Beijing 100085, China \\ ${ }^{e}$ Barbara Hardy Institute, University of South Australia, South Australia 5095, Australia \\ E-mail: John.awad@mymail.unisa.edu.au
}

\begin{abstract}
Problems caused by dissolved organic matter (DOM) present in drinking water include its constituent compounds being precursors in the formation of disinfection by-products that pose risks to human health. The prediction of trihalomethanes (THM) formation is highly challenging due to a wide range of impacting factors, including the concentration and character of $\mathrm{DOM}, \mathrm{pH}$, temperature and the presence of halide anions $\left(\mathrm{Cl}^{-}, \mathrm{Br}^{-}\right)$in drinking water. The aim of the research reported here was to develop model(s) for prediction of THM formation potential (THMFP) including the four compounds, chloroform, bromodichloromethane, chlorodibromomethane and bromoform, based on the character of precursor organics sourced from discrete catchments of a drinking water reservoir.

Water samples were collected from six discrete zero-order catchments (ZOCs) of the Myponga reservoircatchment, South Australia under three land management practices (Australian native vegetation, pine plantation, grasslands) with varying soil textures. Water samples were also collected from the main stream (Myponga River) and the Myponga Reservoir. Water samples from the ZOCs were collected at both the surface and subsurface ( $\sim 60 \mathrm{~cm}$ depth) and were treated by alum coagulation under laboratory conditions to simulate conventional treatment for removal of organic compounds. Samples were analyzed for dissolved organic carbon (DOC) and UV-visible absorbance to measure and characterize the DOM. Raw and alum treated waters were then tested for THMFP under standardized laboratory conditions.

Mathematical models were developed to predict THMFP and abundances of constituent compounds from the DOM concentration and character, and bromide $(\mathrm{Br})$ ion concentration (to $\sim 0.5 \mathrm{mg} / \mathrm{L}$ ), based on regression analysis. A linear model $\left(\mathrm{R}^{2}=0.97\right.$, T-test $=0.92$ and standard error: $\left.\mathrm{SE}=32.9 \mu \mathrm{g} / \mathrm{L}\right)$ was developed to describe the relationship between THMFP and the character of DOM in terms of aromatic and non-aromatic compounds. Similarly, a linear model $\left(\mathrm{R}^{2}=0.95\right.$, T-test $=0.89$ and $\left.\mathrm{SE}=33.9 \mu \mathrm{g} / \mathrm{L}\right)$ was fitted to describe the relationship between chloroform $\left(\mathrm{CHCl}_{3}\right)$ concentration and DOM character. For modelling of the formation of constituent THM compounds, the percentage formation (\%) of $\mathrm{CHCl}_{3}$ was predicted by using the same independent variables (DOC, UV absorbance at $254 \mathrm{~nm}\left(\mathrm{UV}_{254}\right)$ and $\left.\mathrm{Br}\right),\left(\mathrm{R}^{2}=0.85\right.$, T-test $=0.99$ and $\left.\mathrm{SE}=8.8 \%\right)$. Using the relative abundance of chloroform to THMFP, the percentages of bromodichloromethane and chlorodibromomethane were estimated using a power function equation $\left(\mathrm{R}^{2}=0.99\right)$ for bromodichloromethane and an exponential function equation $\left(\mathrm{R}^{2}=0.98\right)$ for chlorodibromomethane. From previous models, the concentration of each individual THM compound can be estimated. From this study, it was found that data of the character of DOM and Br present in waters of catchments with discrete land use can be related to THMFP and abundances of constituent compounds.
\end{abstract}

Keywords: Catchment runoff, sub-surface flow, trihalomethane formation potential (THMFP), organic character 
Awad et al., Modelling THM formation potential based on the character of organics- in catchments and drinking water sources

\section{INTRODUCTION}

Water quality in catchment fed reservoirs is largely influenced by land management practices within the catchment and catchment properties such as vegetation type and loadings, topography, climate and soils (Nosrati et al., 2012; Yang et al., 2013). Organics present in drinking water reservoirs can pose significant aesthetic problems and health risks that need to be addressed through treatment processes for potable supply including formation of disinfection by-products (DBPs, including trihalomethanes, haloacetic acids, iodoacids, halonitromethanes, and nitrosamines) when organics react with chemical disinfectants (Richardson and Postigo, 2012). The concentration and character of dissolved organic matter (DOM) significantly influence raw and treated water quality and chemical disinfectant decay and DBP formation in treated waters (Nosrati et al., 2012). Chow et al. (2011) reported that significant amounts of DBP precursors in sub-surface waters can be attributed to the leaching of deciduous litter of surrounding vegetation, emphasizing the influence catchment sub-surface water can have on reservoir water quality.

For drinking water disinfection, chlorine is widely used to control growth of pathogenic micro-organisms in supply systems with short hydraulic retention times. Drinking water DBPs such as trihalomethane (THM) are formed by the reaction of chlorine-based disinfectants with naturally occurring organic matter (Richardson and Postigo, 2012). THM formation in distribution systems is a function of chlorination and the quality of the water being treated (Courtis et al., 2009), especially the concentration and character of organic matter. In raw (untreated) drinking waters with high relative abundances of hydrophobic, aromatic and humic compounds, there is generally greater THM formation following chlorination than in treated waters with non-aromatic, hydrophilic compounds and/or fulvic acids (Jung and Son, 2008). Zhao et al. (2006) reported that in river water (Pearl River, Guangzhou, China), low molecular weight (LMW) DOM compounds were the main THM precursors. In addition to organic matter, physical and chemical factors also influence the formation of THM, such as bromide $(\mathrm{Br})$ ion concentration in raw waters, $\mathrm{pH}$ and temperature (Brown et al., 2011).

Some factors such as temperature and $\mathrm{pH}$ have been reported to have consistent, albeit complex effects, on THM formation (Roccaro et al., 2014); while the effects of DOM concentration and properties are less well understood as the reactivity of THM precursors is site-specific and varies in response to the amount that has reacted (Roccaro et al., 2008). Model input parameters such as total or dissolved organic carbon (TOC and DOC) concentration provide general information on the concentration of precursor material but provide no information on the character of organics, unless other data such as UV-visible absorbance data are also included (Yan et al., 2014). A number of studies (Singer et al., 1981; Yoon et al., 2003; Chen and Westerhoff, 2010; Summers et al., 2013) have developed mathematical models to predict THM or THM formation potential (THMFP) concentration in drinking water from generic organic parameters (DOC, TOC or UV $254 \mathrm{~nm}$ ). Few studies have developed models to predict THM or THMFP from measures of DOM character, such as SUVA value, the ratio of absorbance at $254 \mathrm{~nm} / \mathrm{m}$ to DOC concentration (Semerjian et al., 2009), fulvic acid (Rodrigues et al., 2007) and humic-like compounds from fluorescence excitation and emission (F-EEM) spectroscopy (Summers et al., 2013).

The aim of this study was to develop models for the prediction of THMFP, including prediction of the concentrations of each of the four compounds, chloroform, bromodichloromethane, chlorodibromomethane and bromoform, based on the character of precursor organics in runoff and subsurface waters sourced from discrete catchments of a drinking water reservoir.

\section{MATERIAL AND METHODS}

\subsection{Water samples}

Water samples used for development of models of THMFP and the formation of constituent THM compounds (chloroform, bromoform, chlorodibromomethane and bromodichloromethane) were collected from six discrete zero-order catchments (ZOCs) of the Myponga reservoir-catchment (35.405S and 138.429E), South Australia under three land management practices (Australian native vegetation, pine plantation, grassland) with varying soil textures. Water samples were also collected from the Myponga Reservoir and the Myponga River. Landuses, dominant vegetation, average slopes and soil descriptions of the ZOCs have been previously reported in detail (Awad et al., 2015). The key features of the study sites are as follows: Site 1: native vegetation on sandy soil (35.411S and 138.425E); Site 2: pine on sandy soil (35.390S and 138.450E); Site 3: grass on sand over sandy clay (35.380S and 138.459E); Site 4: native vegetation on sandy clay loam over sandy clay (35.399S and 138.442E); Site 5: pine on sandy clay loam over sandy loam (35.397S and 138.432E); Site 6: grass on sandy clay loam over sandy clay $(35.402 \mathrm{~S}$ and $138.447 \mathrm{E})$. ZOCs were instrumented with surface runoff collection and sub-surface $(\sim 60 \mathrm{~cm})$ devices as detailed by Awad et al. (2015). 
Awad et al., Modelling THM formation potential based on the character of organics- in catchments and drinking water sources

Water samples were diluted if required until the DOC concentration was less than $20 \mathrm{mg} / \mathrm{L}$, and treated using a coagulation/flocculation process at ambient temperature and at $\mathrm{pH} 6 \pm 0.1$ using aluminium sulphate (alum) as $\mathrm{Al}_{2}\left(\mathrm{SO}_{4}\right)_{3} \cdot 18 \mathrm{H}_{2} \mathrm{O}$. A high dose ( $\mathrm{HD}>2$ times the estimated enhanced dose from the $\mathrm{mEnCo}^{\mathcal{C}}$ model (van Leeuwen et al., 2009) was used to distinguish DOM that could be removed by coagulation from that which is highly recalcitrant to removal.

\subsection{DOM Concentration and Character}

The DOC and UV absorbance measurements were made on water (raw and treated) samples pre-filtered through $0.45 \mu \mathrm{m}$ pre-rinsed sterile cellulose membrane filters. DOC concentration was determined using a TOC analyser (Model 900, Sievers Instruments). UV absorbance at $254 \mathrm{~nm}\left(\mathrm{UV}_{254}\right)$ was measured using a spectro-photometer (UV-120, MIOSTECH Instruments) using $1 \mathrm{~cm}$ quartz cuvettes. The average, maximum and minimum values of DOM concentration and character are presented in Table 1 for surface waters, catchment runoff and subsurface waters prior to and after alum treatment.

Table 1. Mean, maximum and minimum values of water quality parameters and THMFP of surface waters, catchment runoff and subsurface waters.

\begin{tabular}{|c|c|c|c|c|c|c|c|c|c|c|}
\hline \multirow{2}{*}{ Parameters } & \multirow{2}{*}{ Unit } & \multirow{2}{*}{$\begin{array}{r}\text { Surface } \\
\text { Mean }\end{array}$} & \multirow[b]{2}{*}{ Max } & \multirow[b]{2}{*}{ Min } & \multirow{2}{*}{$\frac{\text { Runoff }}{\text { Mean }}$} & \multirow[b]{2}{*}{ Max } & \multirow[b]{2}{*}{ Min } & \multirow{2}{*}{$\frac{\text { Subsurface }}{\text { Mean }}$} & \multirow[b]{2}{*}{ Max } & \multirow[b]{2}{*}{ Min } \\
\hline & & & & & & & & & & \\
\hline $\mathrm{n}$ & & 26 & & & 13 & & & 26 & & \\
\hline $\mathrm{UV}_{254}$ & $\mathrm{~cm}^{-1}$ & 0.29 & 0.63 & 0.04 & 0.23 & 0.56 & 0.02 & 0.21 & 0.58 & 0.01 \\
\hline DOC & $\mathrm{mg} / \mathrm{L}$ & 9.97 & 19.06 & 2.28 & 5.76 & 12.92 & 1.11 & 5.82 & 12.13 & 1.08 \\
\hline $\mathrm{Br}$ & $\mathrm{mg} / \mathrm{L}$ & 0.35 & 0.47 & 0.17 & 0.16 & 0.47 & 0.00 & 0.08 & 0.36 & 0.00 \\
\hline THMFP & $\mu \mathrm{g} / \mathrm{L}$ & 333 & 649 & 73 & 220 & 528 & 20 & 216 & 623 & 19 \\
\hline $\mathrm{CHCl}_{3}$ & $\mu \mathrm{g} / \mathrm{L}$ & 194 & 482 & 28 & 176 & 372 & 18 & 189 & 594 & 12 \\
\hline $\mathrm{CHCl}_{2} \mathrm{Br}$ & $\mu \mathrm{g} / \mathrm{L}$ & 99 & 162 & 28 & 32 & 150 & 1 & 23 & 104 & 3 \\
\hline $\mathrm{CHBr}_{2} \mathrm{Cl}$ & $\mu \mathrm{g} / \mathrm{L}$ & 37 & 84 & 8 & 10 & 44 & 0 & 4 & 33 & 0 \\
\hline $\mathrm{CHBr}_{3}$ & $\mu \mathrm{g} / \mathrm{L}$ & 3 & 9 & 0 & 1 & 9 & 0 & 0 & 3 & 0 \\
\hline $\mathrm{CHCl}_{3}$ & $\%$ & 51.0 & 77.8 & 26.7 & 80.3 & 98.6 & 24.5 & 82.0 & 97.5 & 39.7 \\
\hline $\mathrm{CHCl}_{2} \mathrm{Br}$ & $\%$ & 32.6 & 40.8 & 19.9 & 14.1 & 38.9 & 1.4 & 14.9 & 37.7 & 2.5 \\
\hline $\mathrm{CHBr}_{2} \mathrm{Cl}$ & $\%$ & 14.9 & 39.1 & 2.3 & 4.7 & 31.7 & 0.0 & 2.8 & 20.6 & 0.0 \\
\hline $\mathrm{CHBr}_{3}$ & $\%$ & 1.5 & 4.5 & 0.0 & 0.7 & 6.5 & 0.0 & 0.2 & 3.2 & 0.0 \\
\hline
\end{tabular}

Where: $\mathrm{n}$, number of samples; $\mathrm{UV}_{254}$, UV absorbance at wavelength $254 \mathrm{~nm}$; DOC, dissolved organic carbon concentration; Br, bromide ion concentration in raw waters; THMFP, trihalomethane formation potential; $\mathrm{CHCl}_{3}$, chloroform formation potential; $\mathrm{CHCl} \mathrm{Br}_{2}$, bromodichloromethane formation potential; $\mathrm{CHBr}_{2} \mathrm{Cl}$, chloro-dibromomethane formation potential; $\mathrm{CHBr}_{3}$, bromoform formation potential.

\subsection{THMFP and Bromide ions concentration}

Trihalomethane formation potential and the formation of constituent THM compounds were determined for water samples (DOC less than $20 \mathrm{mg} / \mathrm{L}$ ) before and after alum treatment using a headspace sampler (Perkin Elmer, TurboMatrix 110) and a gas-chromatograph with electron-capture detection (Perkin Elmer Clarus ${ }^{\circledR} 500$ GC). THM were formed under controlled laboratory conditions of $35^{\circ} \mathrm{C}, \mathrm{pH} 7.4$ for $4 \mathrm{~h}$, with $20 \mathrm{mg} / \mathrm{L}$ chlorine addition. The THMFP procedure used was a standardized method applied to compare between the reactivities of organics present in catchment waters before and after alum treatment, with chlorine. From this data, models were developed. Br concentration was measured using Standard Method 4110 (Eaton et al., 2005). The average, maximum and minimum values of THMFP and its species and $\mathrm{Br}$ concentration are also presented in Table 1 .

\subsection{Model(s) calibration and statistical analysis}

Models were developed through non-linear regression using IBM SPSS Statistics 21 software. Microsoft Excel 2010 was used to compare predicted and measured data and for statistical analysis (F-test, Student's T test and standard error values: SE: Eq. 1). Where F-test values were more than 0.5 , the T-test with equal variance was used. T-test values $>0.5$ indicate that there are no significant differences between measured and model fitted data, while T-test values $<0.5$ indicate that these are different.

$\mathrm{SE}=\sqrt{\frac{\sum(\text { Predicted }- \text { Measured })^{2}}{\mathrm{n}}}$ 
Awad et al., Modelling THM formation potential based on the character of organics- in catchments and drinking water sources

\section{RESULTS AND DISCUSSION}

\subsection{Model(s) development}

From samples $(n=15)$ where Br was not detected, the following equation (Eq. 7) was determined to describe the relationship between THMFP and DOM concentration, measured as DOC, and the character of DOM i.e. aromatic and non-aromatic compounds. The following steps (Eqs. 2:6) were carried out to develop this equation (Eq. 7).

DOM present in runoff and sub-surface waters can be characterized based on the constituent aromatic and nonaromatic compounds (Eq.2). Specific UV absorbance (SUVA) values, was used to estimate the proportion of aromatic compounds in DOM, according to the method of Weishaar et al. (2003), which uses Eq. 3. From Eq. $2 \& 3$, the relation between UV absorbance at $254\left(\mathrm{UV}_{254}\right)$ and the percentage of aromatic (Eq. 4) and nonaromatic (Eq. 5) compounds can be estimated.

$\mathrm{DOC}=(\%$ Aromatic $+\%$ NonAromatic $) \times \frac{\mathrm{DOC}}{100}=$ AromDOC + NonAromDOC

Where: $\%$ Aromatic $+\%$ NonAromatic $=100$; AromDOC is the aromatic concentration $(\%$ Aromatic $\times$ DOC/100), NonAromDOC is the non-aromatic concentration [(100 - \% Aromatic $) \times$ DOC/100]

$\%$ Aromatic $=$ a SUVA $+b$

AromDOC $=(\mathrm{a} \mathrm{SUVA}+\mathrm{b}) \times \frac{\mathrm{DOC}}{100}=\mathrm{aUV}_{254}+\mathrm{b} \frac{\mathrm{DOC}}{100}$

NonAromDOC $=$ DOC $-\mathrm{a} \mathrm{UV} 254-\mathrm{b} \frac{\mathrm{DOC}}{100}=(100-\mathrm{b}) \times \frac{\mathrm{DOC}}{100}-\mathrm{a} \mathrm{UV}_{254}$

Under standardized conditions, and with $\mathrm{Br}$ concentration less than $0.025 \mathrm{mg} / \mathrm{L}$, an assumption made is that DOM concentration and character are the main variables that affect the formation of THM and can be described by Eq. 7:

THMFP $\alpha$ DOC

THMFP $\alpha($ AromDOC + NonAromDOC $)$

$\mathrm{THMFP}=\mathrm{C} \times($ AromDOC $)+\mathrm{d} \times($ NonAromDOC $)+\mathrm{e}$

THMFP $=\mathrm{a}(\mathrm{c}-\mathrm{d}) \times \mathrm{UV}_{254}+[(\mathrm{c} \times \mathrm{b})+(100 \times \mathrm{d})-(\mathrm{d} \times \mathrm{b})] \times \frac{\mathrm{DOC}}{100}+\mathrm{e}$

$\mathrm{THMFP}=\mathrm{g} \times \mathrm{UV}_{254}+\mathrm{h} \times \frac{\mathrm{DOC}}{100}+\mathrm{e}[$ where $\mathrm{g}=\mathrm{a}(\mathrm{c}-\mathrm{d})$ and $\mathrm{h}=(\mathrm{c} \times \mathrm{b})+(100 \times \mathrm{d})-(\mathrm{d} \times \mathrm{b})]$

To account for bromide effects and based on the available data ( $\mathrm{n}=65$ for Br concentration to $0.5 \mathrm{mg} / \mathrm{L}$ ), the constant parameters ( $g$ and $h$ ) for the previous equation (Eq. 7) were assumed to increase with Br concentration (the existence of $\mathrm{Br}$ leads to more THMFP). From this, mathematical relationships were established between the DOM character, and $\mathrm{Br}$ ion concentration (to $\sim 0.5 \mathrm{mg} / \mathrm{L}$ ) with THMFP (Eq. 8 ).

$$
\text { THMFP }=\mathrm{g} \times\left(1+\mathrm{k}_{1} \times \mathrm{Br}\right) \times \mathrm{UV}_{254}+\mathrm{h} \times\left(1+\mathrm{k}_{2} \times \mathrm{Br}\right) \times \frac{\mathrm{DOC}}{100}+\mathrm{e} \times\left(1+\mathrm{k}_{3} \times \mathrm{Br}\right)
$$

Where: a, b, c, d, g, h, e, $\mathrm{k}_{1}, \mathrm{k}_{2}$ and $\mathrm{k}_{3}$ (Eqs. 3:8) are the models constants.

For development of models that describe the relative abundance and concentration of constituent THM compounds, the following steps were carried out. For prediction of chloroform $\left(\mathrm{CHCl}_{3}\right)$ concentration, an assumption was made that the $\mathrm{CHCl}_{3}$ concentration is equal to total THM formation potential for the samples $(\mathrm{n}=15)$ where $\mathrm{Br}$ was not detected. The previous equation (Eq. 7) was used and the constant parameters were estimated. The relative abundances of $\mathrm{CHCl}_{3}$ to $\mathrm{THM}$ have an inverse correlation with bromide ion concentration in the raw waters (the existence of Br leads to more bromide species), (Chen and Westerhoff, 2010). Thus, a mathematical relationship was established between the DOM character and Br concentration with $\mathrm{CHCl}_{3}$ (Eq. 9).

$$
\mathrm{CHCL}_{3}=\frac{\mathrm{g} \times \mathrm{UV}_{254}}{\left(1+\mathrm{k}_{1} \times \mathrm{Br}\right)}+\frac{\mathrm{h} \times \mathrm{DOC}}{100 \times\left(1+\mathrm{k}_{2} \times \mathrm{Br}\right)}+\frac{\mathrm{e}}{\left(1+\mathrm{k}_{3} \times \mathrm{Br}\right)}
$$


Awad et al., Modelling THM formation potential based on the character of organics- in catchments and drinking water sources

According to van Leeuwen et al., (2011) and Roccaro et al., (2014), the relative abundances of constituent THM compounds to total THM are a function of the ratio of bromide concentration to the chlorine consumed. van Leeuwen et al. (2011) used an exponential function to describe the relationship between the percentage formation (\%) of chloroform and $\mathrm{Br} /$ chlorine consumed ratio. However for the THMFP test, a very high dose of chlorine (20 mg/L excess free chlorine) was used and therefore the chlorine dose was assumed to not be an independent variable for THM formation.

In order to predict the $\% \mathrm{CHCl}_{3}$ values, by using equation 6 , the relative abundances of $\mathrm{CHCl}_{3}$ were estimated to be a function on DOM concentration and character for data acquired with no Br concentration, Eq. 10. The Br ion concentration effect was taken into account at Eq. 11.

$\% \frac{\mathrm{CHCL}_{3}}{\text { THMFP }}=\left[\frac{\mathrm{a}_{1}\left(\mathrm{c}_{1}-\mathrm{d}_{1}\right) \times \mathrm{UV}_{254}+\left[\left(\mathrm{c}_{1} \times \mathrm{b}_{1}\right)+\left(100 \times \mathrm{d}_{1}\right)-\left(\mathrm{d}_{1} \times \mathrm{b}_{1}\right)\right] \times \frac{\mathrm{DOC}}{100}}{\mathrm{a}_{1}\left(\mathrm{c}_{2}-\mathrm{d}_{2}\right) \times \mathrm{UV}_{254}+\left[\left(\mathrm{c}_{2} \times \mathrm{b}_{1}\right)+\left(100 \times \mathrm{d}_{2}\right)-\left(\mathrm{d}_{2} \times \mathrm{b}_{1}\right)\right] \times \frac{\mathrm{DOC}}{100}}+\mathrm{e}\right] \times 100$
$\% \frac{\mathrm{CHCL}_{3}}{\text { THMFP }}=\left[\frac{\mathrm{a}_{1}\left(\mathrm{c}_{1}-\mathrm{d}_{1}\right) \times \mathrm{UV}_{254}+\left[\left(\mathrm{c}_{1} \times \mathrm{b}_{1}\right)+\left(100 \times \mathrm{d}_{1}\right)-\left(\mathrm{d}_{1} \times \mathrm{b}_{1}\right)\right] \times \frac{\mathrm{DOC}}{100}}{\mathrm{a}_{1}\left(\mathrm{c}_{2}-\mathrm{d}_{2}\right) \times \mathrm{UV}_{254}+\left[\left(\mathrm{c}_{2} \times \mathrm{b}_{1}\right)+\left(100 \times \mathrm{d}_{2}\right)-\left(\mathrm{d}_{2} \times \mathrm{b}_{1}\right)\right] \times \frac{\mathrm{DOC}}{100}} \times\left(1+\mathrm{k}_{1} \times \mathrm{Br}\right)+\mathrm{e} \times\left(1+\mathrm{k}_{2} \times \mathrm{Br}\right)\right] \times 100$

Using the relative abundance of chloroform to THMFP, the percentages of bromodichloromethane $\left(\mathrm{CHCl}_{2} \mathrm{Br}\right)$ and chlorodibromomethane $\left(\mathrm{CHBr}_{2} \mathrm{Cl}\right)$ were estimated using a power function (Eq.12) for $\mathrm{CHCl}_{2} \mathrm{Br}$ and an exponential function (Eq.13) for $\mathrm{CHBr}_{2} \mathrm{Cl}$.

$$
\begin{aligned}
& \% \mathrm{CHCl}_{2} \mathrm{Br}=\mathrm{a}+\mathrm{b} \times\left(\% \mathrm{CHCl}_{3}\right)^{\mathrm{c}} \\
& \% \mathrm{CHBr}_{2} \mathrm{Cl}=\mathrm{a}+\mathrm{b} \times \mathrm{Exp}^{-\mathrm{c} \times \%} \mathrm{CHCl}_{3} \text { at } \% \mathrm{CHCl}_{3} \leq 92 \% \text { while, } \% \mathrm{CHBr}_{2} \mathrm{Cl}=0.0 \text { elsewhere }
\end{aligned}
$$

\subsection{Coefficient parameters and the statistical analysis results}

Model coefficient parameters and the statistical analysis results for developed models are presented in Table 2. $\mathrm{R}^{2}$ values were greater than 0.85 and $\mathrm{T}$-test values were greater than 0.89 (indicating no significant differences between measured and model fitted data). These statistical analyses (Table 2) indicate that the DOM character in terms of aromatic compounds identified by UV absorbance at $254 \mathrm{~nm}$ with DOC and $\mathrm{Br}$ concentrations are suitable parameters for predicting THM formation potential and the constituent species.

\begin{tabular}{|c|c|c|c|c|c|c|c|c|c|c|c|c|c|c|c|}
\hline Eq. & \# & $\mathrm{a}$ & $\mathrm{b}$ & $\mathrm{c}$ & $\mathrm{d}$ & $\mathrm{g}$ & $\mathrm{h}$ & $\mathrm{k}_{1}$ & $\mathrm{k}_{2}$ & $\mathrm{k}_{3}$ & $\mathrm{e}$ & $\mathrm{R}^{2}$ & $\begin{array}{c}\text { F- } \\
\text { test }\end{array}$ & $\begin{array}{c}\mathrm{T}- \\
\text { test }\end{array}$ & $\mathrm{SE}^{\$}$ \\
\hline 6 & & 1.37 & 3.66 & 568 & -16.3 & & & & & & -10.1 & 0.96 & 0.94 & 0.99 & 37.7 \\
\hline 8 & & & & & & 799 & 503 & -0.34 & 2.1 & -14.5 & -10.1 & 0.97 & 0.94 & 0.92 & 32.9 \\
\hline 9 & & & & & & 782 & 349 & 0.32 & 7.1 & -1.2 & -9.5 & 0.95 & 0.83 & 0.89 & 33.9 \\
\hline \multirow[t]{2}{*}{11} & 1 & 31.8 & 7.58 & -18.8 & -26.2 & & & 18.4 & 5.5 & & 1.4 & 0.85 & 0.55 & 0.99 & 8.8 \\
\hline & 2 & & & 40.7 & 51.5 & & & & & & & & & & \\
\hline 12 & & 41.9 & $-3 \times 10^{-4}$ & 2.57 & & & & & & & & 0.99 & 0.99 & 0.99 & 0.8 \\
\hline 13 & & -6.63 & 72.70 & 0.026 & & & & & & & & 0.98 & 0.97 & 0.99 & 0.8 \\
\hline
\end{tabular}

Table 2. The models coefficient parameters and statistical analysis results.

\#, refers to constant number in equation; \$, Standard deviation's unit: $\mu \mathrm{g} / \mathrm{L}$ for Eq. 6 to Eq. 9 vs \% for Eq.11 to Eq.13

The measured and model fitted values for equations 8, 9 and 11 are presented in Figure 1. For the THMFP model, Eq. $8\left(\mathrm{R}^{2}=0.97\right.$, T-test $=0.92$ and $\left.\mathrm{SE}=32.9 \mu \mathrm{g} / \mathrm{L}\right)$, the coefficient of $\mathrm{UV}_{254}(\mathrm{~g}=799$, see Eq. 8) was significantly greater than that of DOC $(\mathrm{h} / 100=5.03)$, indicating that THM is more likely to be produced from UV absorbing organic compounds than DOC overall, which includes hydrophilic, non-aromatic compounds.

Even though the correlation factors for the $\mathrm{CHCl}_{3}$ model (Eq. 9) and $\% \mathrm{CHCl}_{3}$ (Eq. 11) are slightly less than that for THMFP model (Eq. 8) as shown in Table 2, the DOM character, concentration and Br concentration can be statistically fitted to model $\mathrm{CHCl}_{3}$ concentrations and its relative abundance (Eq. 9: $\mathrm{R}^{2}=0.95$, T-test $=$ 0.89 and $\mathrm{SE}=33.9 \mu \mathrm{g} / \mathrm{L}$; Eq. 11: $\mathrm{R}^{2}=0.85, \mathrm{~T}$-test $=0.99$ and $\mathrm{SE}=8.8 \%$ ). Similarly to the THMFP model, the coefficient of $\mathrm{UV}_{254}$ was significantly greater than that of DOC, as shown in Table 2 for the $\mathrm{CHCl}_{3}$ model. 
Awad et al., Modelling THM formation potential based on the character of organics- in catchments and drinking water sources

The relative abundances of $\mathrm{CHCl}_{2} \mathrm{Br}$ ranged from $1.4 \%$ to $40.8 \%$ and that of $\mathrm{CHBr}_{2} \mathrm{Cl}$ ranged from being not detected to $39.1 \%$. Models for prediction of the abundance of $\mathrm{CHCl}_{2} \mathrm{Br}$ and $\mathrm{CHBr}_{2} \mathrm{Cl}$ relative to $\mathrm{CHCl}_{3}(\mathrm{Eq}$. 12 and Eq. 13 respectively) fitted reasonably well, as shown in Table 2 (Eq. 12: $\mathrm{R}^{2}=0.99$, T-test $=0.99$ and $\mathrm{SE}=0.8 \%$; Eq. 13: $\mathrm{R}^{2}=0.98$, T-test $=0.99$ and $\left.\mathrm{SE}=0.8 \%\right)$ and Figure 2. However these models (Eqs. 12 and 13) are dependent on the accurate prediction of the abundance of chloroform.
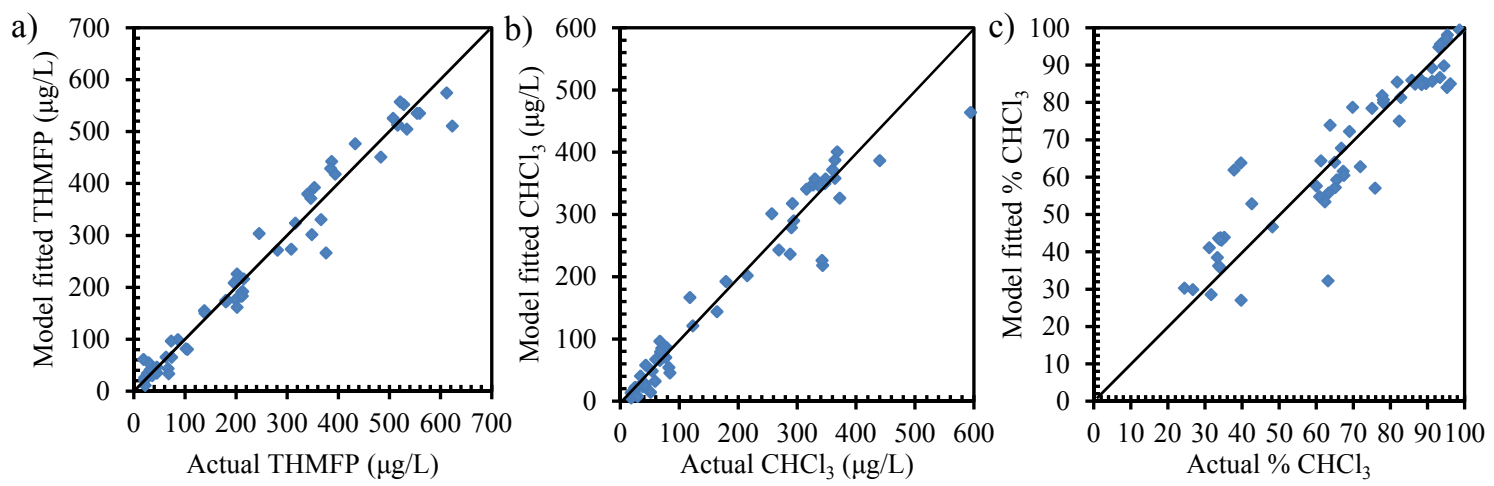

Figure 1. Actual vs. model fitted values of a) THMFP, b) $\mathrm{CHCl}_{3}$ and c) $\% \mathrm{CHCl}_{3}$
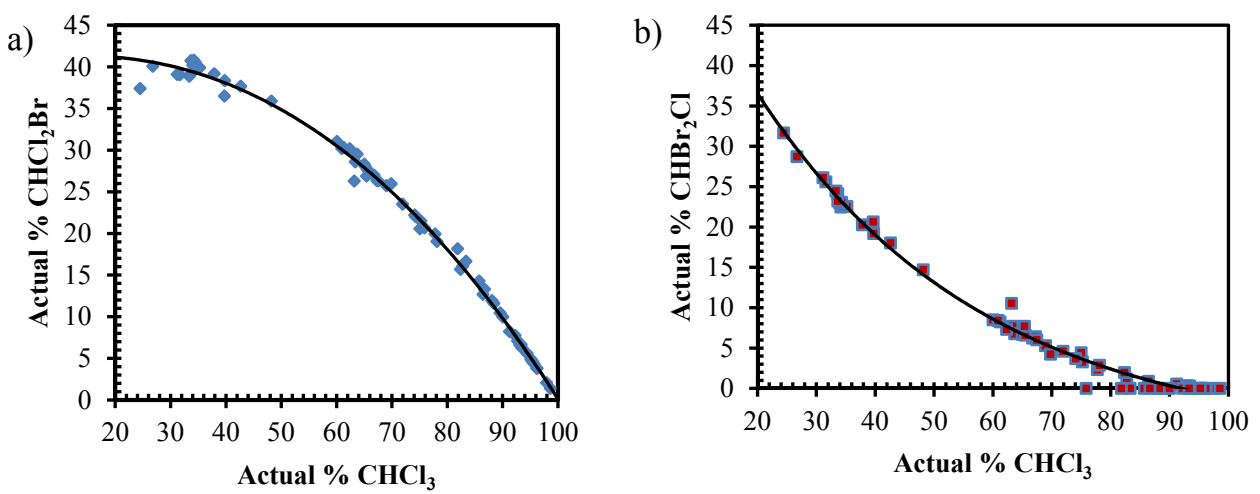

Figure 2. Relationship between $\% \mathrm{CHCl}_{3}$ with a) $\% \mathrm{CHCl}_{2} \mathrm{Br}$, and with b) $\% \mathrm{CHBr}_{2} \mathrm{Cl}$

\section{CONCLUSIONS AND FURTHER WORK}

The character of DOM and the concentration $\mathrm{Br}$ present in waters of catchments with discrete landuse can be used to predict THMFP and abundances of constituent compounds. Models of THMFP and the concentrations of it is four analogues based on the character of precursor organics (in terms of aromatic compounds identified by UV absorbance at $254 \mathrm{~nm}$ ) in runoff and subsurface waters sourced from discrete catchments of a drinking water reservoir, were developed. In future work, the models will be further evaluated using waters sourced from ZOCs from the Happy Valley Reservoir and Mount Bold Reservoir of South Australia. Further development of the models will be based on the character of precursor organics in terms of molecular weight distribution or relative abundances of organic compounds, i.e. humic-, fulvic- and protein-like compounds.

\section{ACKNOWLEDGEMENTS}

The authors gratefully acknowledge the financial support provided by the Australian Research Council under Grant LP110200208, SA Water and the SA Department for Environment, Water and Natural Resources and the Goyder Institute for Water Research. The authors thank Mr Jonathan Cohen for his support in field work.

\section{REFERENCES}

Awad, J., J. van Leeuwen, D. Abate, M. Pichler, E. Bestland, D.J. Chittleborough, N. Fleming, J. Cohen, J. Liffner, and M. Drikas (2015). The effect of vegetation and soil texture on the nature of organics in runoff from a catchment supplying water for domestic consumption. Science of The Total Environment, 529, 7281.

Brown, D., J. Bridgeman, and J. West (2011). Predicting chlorine decay and THM formation in water supply systems. Reviews in Environmental Science and Bio/Technology, 10, 79-99. 
Awad et al., Modelling THM formation potential based on the character of organics- in catchments and drinking water sources

Chen, B., and P. Westerhoff (2010). Predicting disinfection by-product formation potential in water. Water Research, 44, 3755-3762.

Chow, A.T., A.T. O'Geen, R.A. Dahlgren, F.J. Díaz, K.-H. Wong, and P.-K. Wong (2011). Reactivity of Litter Leachates from California Oak Woodlands in the Formation of Disinfection By-Products. Journal of Environmental Quality, 40, 1607-1616.

Courtis, B.J., J.R. West, and J. Bridgeman (2009). Chlorine demand-based predictive modeling of THM formation in water distribution networks. Urban Water Journal, 6, 407-415.

Eaton, A.D., L.S. Clesceri, and A.E. Greenberg (2005). Standard Methods for The Examination of Water and Waste Water, 21st ed. American Public Health Association, Washington, DC.

Jung, C.-W., and H.-J. Son (2008). The relationship between disinfection by-products formation and characteristics of natural organic matter in raw water. Korean Journal of Chemical Engineering, 25, 714720.

Nosrati, K., G. Govers, and E. Smolders (2012). Dissolved organic carbon concentrations and fluxes correlate with land use and catchment characteristics in a semi-arid drainage basin of Iran. CATENA, 95, 177-183.

Richardson, S., and C. Postigo (2012). Drinking Water Disinfection By-products. in: Barceló, D. (Ed.). Emerging Organic Contaminants and Human Health. Springer Berlin Heidelberg, pp. 93-137.

Roccaro, P., H.-S. Chang, F.G.A. Vagliasindi, and G.V. Korshin (2008). Differential absorbance study of effects of temperature on chlorine consumption and formation of disinfection by-products in chlorinated water. Water Research, 42, 1879-1888.

Roccaro, P., G.V. Korshin, D. Cook, C.W.K. Chow, and M. Drikas (2014). Effects of pH on the speciation coefficients in models of bromide influence on the formation of trihalomethanes and haloacetic acids. Water Research, 62, 117-126.

Rodrigues, P.M.S.M., J.C.G. Esteves da Silva, M.C.G. Antunes (2007). Factorial analysis of the trihalomethanes formation in water disinfection using chlorine. Analytica Chimica Acta, 595, 266-274.

Semerjian, L., J. Dennis, and G. Ayoub (2009). Modeling the formation of trihalomethanes in drinking waters of Lebanon. Environmental Monitoring and Assessment, 149, 429-436.

Singer, P.C., J.J.B. Iii, G.M. Palen, and A.E. Scrivner (1981). Trihalomethane formation in North Carolina drinking waters. Journal (American Water Works Association), 73, 392-401.

Summers, R.S., K.M.H. Beggs, D.M. McKnight, F.L. Rosario-Ortiz, and J.A. Billica (2013). Watershed Analysis of Dissolved Organic Matter and Control of Disinfection By-Products. Water Research Foundation, U.S.A.

van Leeuwen, J., M. Holmes, U. Kaeding, R. Daly, and D. Bursill, (2009). Development and implementation of the software mEnCo to predict coagulant doses for DOC removal at full-scale WTPs in South Australia. Journal of Water Supply: Research \& Technology-AQUA, 58, 291-298.

van Leeuwen, J.A., D. Cook, C. Chow, G. Kastl, M. Drikas, and D. Wang, (2011). Mathematical models for prediction of trihalomethanes in drinking water. $19^{\text {th }}$ International Congress on Modelling and Simulation, Perth, Australia, December 12-16, pp. 3335-3341.

Weishaar, J.L., G.R. Aiken, B.A. Bergamaschi, M.S. Fram, R. Fujii, and K. Mopper (2003). Evaluation of Specific Ultraviolet Absorbance as an Indicator of the Chemical Composition and Reactivity of Dissolved Organic Carbon. Environmental Science \& Technology, 37, 4702-4708.

Yan, M., G.V. Korshin, and H.-S. Chang (2014). Examination of disinfection by-product (DBP) formation in source waters: A study using log-transformed differential spectra. Water Research, 50, 179-188.

Yang, Y., Z. He, Y. Wang, J. Fan, Z. Liang, and P.J. Stoffella (2013). Dissolved organic matter in relation to nutrients $(\mathrm{N}$ and $\mathrm{P})$ and heavy metals in surface runoff water as affected by temporal variation and land uses - A case study from Indian River Area, south Florida, USA. Agricultural Water Management, 118, 38-49.

Yoon, J., Y. Choi, S. Cho, and D. Lee (2003). Low trihalomethane formation in Korean drinking water. Science of The Total Environment, 302, 157-166.

Zhao, Z.-Y., J.-D. Gu, X.-J. Fan, and H.-B. Li (2006). Molecular size distribution of dissolved organic matter in water of the Pearl River and trihalomethane formation characteristics with chlorine and chlorine dioxide treatments. Journal of Hazardous Materials, 134, 60-66. 